\title{
ミッションフェロー活動報告
}

\section{Annual Report of Mission Fellow Activities}

\author{
ミッションフェロー
}

\section{はじめに}

エレクトロニクス実装学会 (JIEP) ミッションフェロー (MF) は, 若手をはじめとした学会員の増加と学会活動の活 性化を目的として, 2014 年度から, 年度毎にメンバーを入 れ替えながらさまざまな活動を展開してきました。

今年度から本学会誌において「ミッションフェローのひ ろば」でのメンバー自己紹介, MF が主催した各イベント のご報告などを行っております。今回年頭号での年間活動 報告と併せて, 会員の皆様に MF 活動をご理解いただくと ともに, 今後, さまざまな場でお会いする会員の皆様から MF 活動へのご助言いただき, 学会の発展に務めていきた いと考えております。

\section{メンバー構成}

2017 年度は以下図 1 のメンバーで活動しております。産 学官各界の 50 歳未満 (就任時) の若手〜中堅の学会員から 構成されており, 現在は 19 名の MF とその活動の方向性を 示す役割をもつ 3 名のミッションエグゼティブフェロー (MEF) で構成されております。メンバーの学会における立 場もさまざまで, 各技術委員会からの推薦を得た方や MF 任命を機に入会された方もおり, メンバーは各々の専門分 野の立場から，また立場を超えて，学会内の企画を立案・

\begin{tabular}{|c|c|c|c|c|c|c|}
\hline & & & & \multicolumn{3}{|c|}{ エグゼクティブフェロー } \\
\hline ○主査 (株)東芝 & 樋口和人 & プロセス & & \multicolumn{3}{|c|}{ JIEP、秋田銀行 土門 孝彰 } \\
\hline \multirow{2}{*}{$-\bigcirc$ 副査 (株)図研 } & \multirow{2}{*}{ 長谷川清久 } & \multirow{2}{*}{ 実装設計 } & & 長瀬産業(株) & \multicolumn{2}{|c|}{ 折井 靖光 } \\
\hline & & & & 山口大 & \multicolumn{2}{|c|}{ 岡本 和也 } \\
\hline 日本パーカラ价ング (株) & 配島 雄樹 & 表面処理 & 物質・材料 & 研究機構 & 重藤 暁津 & 接合·界面 \\
\hline パナソニック(株) & 石谷 伸治 & 接合技術 & 都立産業技 & 術研究センタ- & 佐野 宏靖 & 回路設計 \\
\hline 富士電機(株) & 渡邊 裕彦 & パワエレ & 富山県立大 & & 畠山友行 & 垪流体工学 \\
\hline リンテック(株) & 田久真也 & プロセス & 大阪大 & & 森永 英二 & \begin{tabular}{|l|l|l|}
$Z^{2}$ \\
\end{tabular} \\
\hline (株)野田テクノ & 服部 篤典 & 生産技術 & 愛知工業大 & & 生津 資大 & ナノテク \\
\hline (株)日立製作所 & 河喜多心哉 & 熱·信頼性 & 産業技術総 & 合研究所 & 藤野 真久 & 3次元央装 \\
\hline (株)AD EKA & 森貴裕 & 実装澍脂 & 東京電機大 & & 野口祐智 & 検查技術 \\
\hline 古河電工(株) & 那須 秀行 & 光実装 & & & & \\
\hline (株)新川 & 子林みどり & プロセス & & & & \\
\hline (株)JCU & 中丸 弥一郎 & 表面処理 & & & & \\
\hline
\end{tabular}

図 1. 2017 年度ミッションフェローメンバー構成
遂行しております。

\section{7年春季講演大会 \\ 『学生のための製造系企業研究会』2017.3.6.}

2015 年から企業会員が多い本学会の特徴を存分に活かせ るとして, 学生向けに企業に於ける研究生活や研究開発の 現場について知ってもらう場を講演大会に設けました。企 業側は JIEP 会員や MF メンバーを中心に学生さんは講演大 会開催校から参加していただきました。

今年も, エレクトロニクス, 素材メーカなど企業 15 社, 研究機関 2 所から担当者がブースにポスターやパンフレッ トを並べ，30名ほど集まった学生さんを相手に，研究開発 の現場の生の声や, 採用過程などを説明されました。今回 も学生さんは開催校である慶應義塾大学矢上キャンパス (理工系学部) 所属の方が多く来てくださり, 企業の方々も 普段あまり公にならない研究開発の紹介などに熱が入り, お互いの関心が一致した会になったと思います。

\section{JPCA Show 2017}

「ミッションフェローブース」2017.6.7 9.

JPCA Show アカデミックプラザにおいて MF ブースを出 展し, ポスターやスライドで MF のアクティビティやメン バーの紹介などの展示を行いました。広報活動の緒に就い

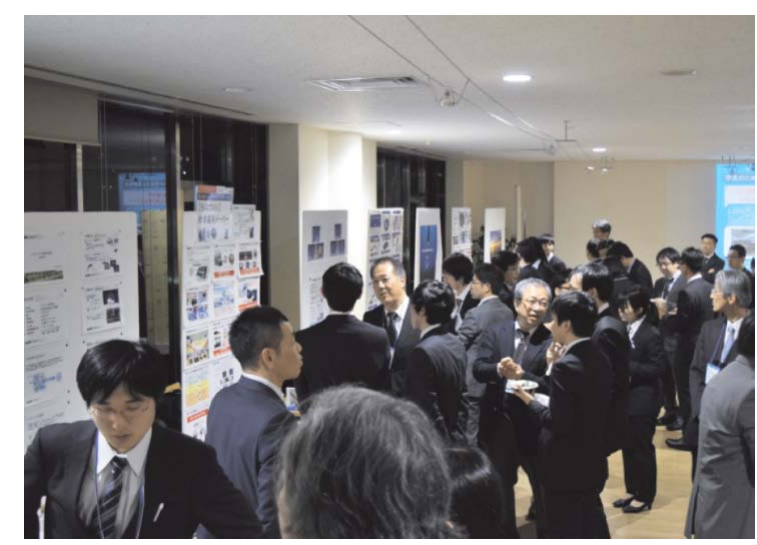

図 2.『学生のための製造系企業研究会』の様子 


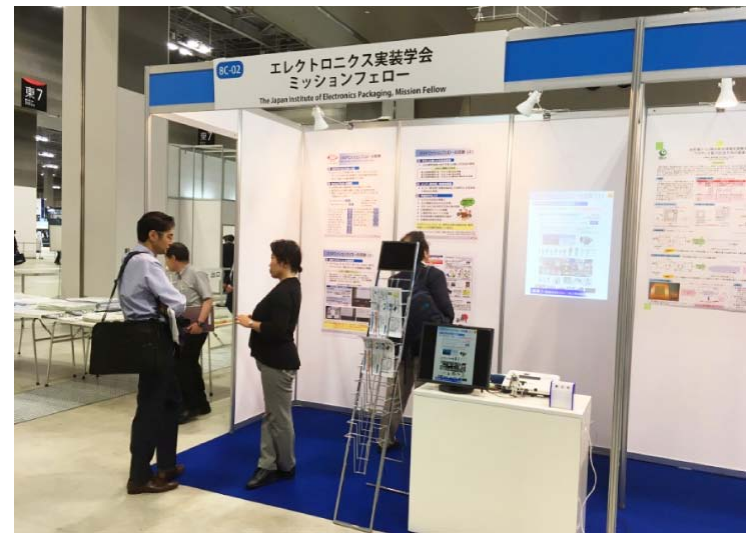

図 3. JPCA Show2017_MF ブースの様子

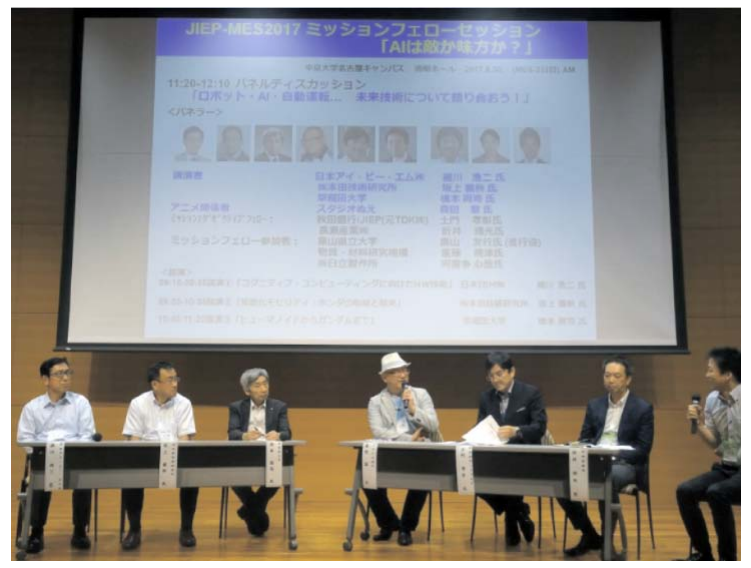

図 4. MES_MF セッションの様子

た点においてはまずまずでしたが，JPCA Showに来場され る方々の目的と今回の展示内容が合致しなかったためか, 来客数は多くは無く, 展示については今後の反省点となり ました。

\section{マイクロエレクトロニクスシンポジウム2017} 「ミッションフェローセッション」2017.8.30.

MES では過去 2 回 MF セッションを開催してきました。 テーマはMF 内で決めており, 2014 年は「触って納得! 近 未来のコア技術」というタイトルで, $3 \mathrm{D}$ 設計技術や人体通 信の最前線の動向を紹介いただきました。また, 2016 年に は「異分野への挑戦〜今, 変わるとき〜」というタイトル で自転車パーツメーカや, 知財専門弁護士, スタートアッ プ支援事業の 3 者から, 異分野と本業のマッシュアップか ら生まれるイノベーションのあり方を紹介いただきまし た。この回からの試みとして, 講演者と MF のメンバーと のパネルディスカッションを企画し, 大きな盛り上がりを
見せました。これを受けて，今年も MF セッションを企画 し,「AIは敵か味方か」というタイトルで, IBMのコグニ ティブコンピュータ, ホンダの自動運転・ロボットの取り 組みやその課題, 早稲田大学のロボット研究開発とガンダ ム・グローバル・チャレンジの取り組みについて，ご講演 いただきました。講演後, 講演者 3 名に加えてアニメ脚本 家や MEFを交えてのパネルディスカッションを行い，大 変盛況に議論が展開されました。今年のテーマは古くて新 しい「ロボット」という切り口であり，技術的な視点にと どまらず，文化的，倫理的な視点までもが議論され，50 分 ではとても収まらない内容でありました。詳細は学会誌 2017 年 11 月号にて報告がなされております。

\section{修善寺ワークショップ2017}

「ミッションフェロー活動報告」2017.10.26, 27 .

本ワークショップは, 30 代以下が $60 \%$ 近くを占めると いう，若手が多く集まるイベントのため，昨年より，ポス ター展示による MF 活動報告を実施しております。今年は, MES-MF セッションのアピールをメインに行いました。

「このような深い議論をしていたとは知りませんでした。 11 月の学会誌はじっくり読ませて頂きます」とのコメント を頂いたり，来年度の講師を推薦頂いたり，MFメンバー に立候補頂いたり アンケート結果からは, MF 活動の認知度が相変わらず低 いという結果となりましたが, 今後も同活動を続け, 認知 度アップに貢献したいと考えております。

おわりに

MF も4期になりましたが，若手・中堅を中心に活動し ていることも有り，職場での多忙な日々の業務の合間を 縫っての運営・企画に奔走して参りました。MESの MF 企 画のように定着してきたものもあれば，軌道に乗らない企 画もありますが，今後とも私たちの活動が学会の活性化に 繋がっていけばと思います。最後になりましたが，MFの 活動に参加していただける方も募集しております。お近く の MF にお声がけしてくだされば幸いです。MFの活動に 対するご意見なども大歓迎です。

文責・藤野真久 / 産業技術総合研究所

(2017.11.27- 受理)

藤野真久 (ふじの まさひさ)

著者紹介

産業技術総合研究所 ナノエレクトロニクス研究部門

3 次元実装, ウエ八接合などに従事. 